\title{
Subliminal Messages for Increasing Self-Esteem: Placebo Effect
}

\author{
Manuel Froufe \\ Autonomous University of Madrid
}

\author{
Cecilia Schwartz \\ New Age Consulting, S.L.
}

\begin{abstract}
Although experimental research has confirmed the capacity of the human cognitive system to process information that does not reach consciousness (unconscious perception), empirical cvidence of the incidence of subliminal verbal messages included on audiotapes claiming to improve human resources and correct some behavioral problems is meager and inconsistent. Our study assesses the influence of "subliminal tapes" designed to increase self-esteent. Participants were randomly assigned to four experimental conditions. One group listened to a lape of music with supra- and subliminal messages; another listened to a tape of music with only subliminal messages; the third group's tape had only music, although the participants believed that it also included subliminal messages; a fourth ("waiting") group heard no tapes, but filled in the same self-csteem scales. Participants in the first three groups filled in the Tennessee Self-Concept Scale (Fitts, 1965) before and after listening to the tape for several days. All groups showed a similar pretest-posttest improvement in self-esteem ( $p \leq .003$ ), except for the waiting group, which did not improve $(p=311)$. This implies that only a placebo effect took place. Our data are not in accordance with those obtained by other authors. We comment upon the possible reasons for these discrepancies.

Key words: sublininal messages, unconscious perception, incretse in self-esteem
\end{abstract}

Aunque la investigación experimental ha constatado la capacidad del sistema cognitivo humano para procesar información que no accede a la conciencia (percepción inconsciente), los datos empíricos sobre la incidencia de los mensajes verbales subliminales incluidos en cintas de audio, comercializadas para potenciar los recursos humanos y corregir algunos problemas conductuales, son muy escasos e inconsistentes. Nuestro estudio evalúa la influencia de "mensajes subliminales", grabados en cinta, diseñados para mejorar la autoestima. Los sujetos fueron asignados aleatoriamente a cuatro condiciones experimentales. Un grupo escuchó una cinta con música y mensajes supra y subliminales; otro, una cinta con música y mensajes subliminales únicamente; en la tercera condición la cinta sólo contenia música, si bien los sujetos creian que también incluía mensajes subliminales; un cuarto grupo ("de espera") fue sometido a las mismas mediciones de autoestima, pero no recibió la cinta. Los participantes de los tres primeros grupos completaron la Escala Tennessee de Autoconcepto (Fitts, 1965) antes y después de haber escuchado la cinta durante varios días. Todos los grupos mostraron una mejora similar entre el pretest y el postest de autoestima $(p \leq .003)$, salvo el de espera, que no mejoró $(\rho=.311)$. Eilo implica que únicamente tiene lugar efecto placebo. Nuestros datos contradicen los obtenidos por algunos otros autores. Se analizan las posibles razones de estas discrepancias.

Palabras clave: mensajes subliminales, percepción inconsciente, mejora de la autoestima

This research was earrjed out with the collaboration of New Age Consulting, which provided the audiotapes. The second author is also the director of $\mathrm{NAC}$.

Correspondence concerning this article should be addressed to Manuel Froufe. Facultad de Psicología. Universidad Autónoma de Madrid. Cantoblanco.28049 Madrid (Spain). E-mail: manuel.froufe@uam.es 
More and more CDs and audiotapes are coming onto the market containing (supposedly) subliminal messages designed to correct various behavioral problems and, in general, improve human resources. They claim, among other things, to help people give up smoking or drinking. lose weight, relieve pain, fear, or depression, increase sclfesteem, improve performance in sports and other personal and professional activities. All of this generates considerable economic activity and involves substantiat personal eftont. which should have the backing of some kind of evidence about the elfectiveness of these tapes and CDs, if they are to be justified. Thus, the first thing we should ask is whether it is possible to process information that, apparently, escapes our notice. Does unconscious perception exist? If so, we would have to determine what kind of information can be processed in this way. The next question we must ask is what eflects could it have? Given that, in recent years, there has been a considerable amount of rescarch on some of these issues in experimental psychology, we should make the most of the information provided-cspecially when the empirical evidence in the applied field is so flimsy.

\section{Unconscious perception}

It is now reasonably well established that the human cognitive system processes much more information than that which reaches consciousness. In recent years, expcrimental laboratory research developed in this field has been highly refined, with quite consistent results in favor of the existence of mconscious perception (and of unconscious memory, learning, thought or, in general terms, "unconscious cognition"; see Froufe, 1997; Ohman \& Soares, 1998; Weiskrantz, 1997). Nevertheless, most of the studies on unconscious perception use simple and isolated stimuli (usually words), presented visually in masked form (Dehaene et al., 1998; Draine \& Greenwald, 1998; Merikle, Joordens, \& Stolz, 1995; Öhman \& Soares, 1998; see also Bornstein \& Pittman, 1992; Weiskrant7, 1997). Currenlly, it is established that apparently "invisible" words or any other stimuli with specific permanent representation in the mental system of knowledge can activate in our minds ideas and connotations related to their meaning.

The catse of oral verbal comnunication is quite different. especially where complex messages are concened. Evidence in favor of semantic processing of "inaudible" verbal information is much mone precarious. And still more so with regard to complex and open messages (without specific permanent representation in the knowledge system), such as sentences, as were studied in this paper.

Certainly, there is some evidence supporting the processing of spoken words that go unnoticed because they do not receive attention: experiments on dichotic listening. It has sometimes been found (Bentin, Kutas, \& Hillyard. 1995; Vila \& Tudela, 1982 ) that unatended words reaching the ear are processed semantically and have some behaviotal or psychophysiological ellect, despite not aceessing consciousness. However, this kind of data hats been considerably more inconsistent and difticult to replicate than that corresponding to the semantic codification of similar masked visual stimuli. As stated above, there is even less evidence regarding the processing of complex atditory cvents, such is sentences. Nevertheless, there are some studies in the field of subliminal psychodynamic activation (SPA; Silverman, 1983), in which effects generated by the processing of inadible sentences have been observed (e.g., Chimera, 1987; Doche-Budzynski \& Budzynski, 1989). But we cannol ignore the enormous methodological difficulties involved in demonstrating that given effects are due to specific elements manipulated in at study and, above all, that these elements go completely unnoticed by the experimental participants (Froufe, 1997; Merikle et al., 1995). Thus, in spite of demonstrations of unconscious perception, the limits of the automatic processing of audio-verbal masked messages are still unknown, although they are probably very narrow. At present, we think that unconscious perception is restricted to an activation process of existing mental representations of information. If so, it is impossible to carry out a constructive interpretation ol unnoticed complex messages:

With regard to the effects induced by the displaty of stimuli that do not reach consciousness, the experimental literature has recorded influences of a cognitive, affective, and electrophysiological nature. However, these are usually subtle effects revealed in experimental tasks especially designed to be highly sensitive to this kind of manipulations. For example, the priming effect, consisting of the transitory facilitation of the recognition of a degraded stimulus and similar operations, due to the previous masked presentation of this stimulus or others related to it. Most studies work with inftuences that could be called "soft effects" of unconscious perception (e.g., Dehaene et al., 1998; MerikJe et al., 1995). Despite some references (Neuberg, 1988; Pittman \& Bornstein, 1989; Silvermatl, 1983), reports of lasting influences on the devclopment of behaviors, decision-making, or personality change in relevant everyday life situations ("hard effects") are rare. These effects have in no way been rigorously verified, as have the solt ones. Thus, it is one thing to discuss unconscious perception of certain stimuli, but it is quite another to assume that this may have tangible eflects in our lives, as clatimed by the subliminal self-help tapes and CDs.

\section{Subliminal self-help tapes}

In research carried out specifically on the incidence of subliminal messages on audiotapes, the results available so far are scarce and inconclusive. Solne researchers have reported influence of this type of message, either as exclusive treatment (Costello \& Budzynski, 1991; Doche-Budzynski \& Budzynski, 1989; Taylor, 1988), or as a complementary 
element within a treatunent that also uses other strategies (Monahan, 199l; Reid, 1990). Nevertheless, some of these studies have been presented by their authors as pilot explorations, whose preliminary results have barely been replicated. Other works have found that lapes with subliminal messages have show no discernible effects whatsoeved (Lenz. 1989; Merikle \& Skanes, 1992; Russell, Rowe, \& Smouse, 1991) or, at best. have only generated a placebo effect (Greenwald, Spangenberg, Pratkanis, \& Skenazi, 1991). The issue of the elfectiveness of this type of material, therefore, remains unsolved (see, in this respect, Durkin, 1998).

Our study emerged from the collaboration between an experimental psychologist interested in the cognitive unconscious and a clinical psychologist who has occasionally used subliminal tapes as therapeutic adjuncts in her professional activity. We were interested in assessing the incidence of this matcrial on the improvement of human resources. From the tapes and CDs with messages in Spanish, we chose those by New Age Consulting (NAC), S.L., designed to increase self-esteem, because we considered this psychological aspect to be one of the most susceptible to this kind of influence. Undoubtedly, such a strongly subjective characteristic as self-concept is also especially vulnerable to placebo effect, due to expectations. In order to detect this type of spurious influence, we included a specific treatment, as well as a waiting group, with the aim of controlling possible effects of extraneous variables due to the passing of time between pretest and posttest and the repetition of measurements. Of course, we also included a condition with subliminal messages, either alone or with similar supraliminal messages. The comparison of these conditions would allow us to distinguish the real incidence of subliminal messages from placebo, as well as all these eflects from the influence of the passing of time and test repetition.

\section{Method}

\section{Participants}

The rescarch was carricd out with junior volunteer students from the Information Sciences Faculty of the Complutense University in Madrid. Of 125 who filled in the self-esteem pretest ( 66 women and 59 men, aged between 18 and 27), only 83 did so correctly and went on to fill in the posttest 48 days later.

\section{Materials}

Tapes. The tapes used wete of 30 -min duration and contained sounds and music composed to induce a state of relaxation. The majority also had a scries of self-affirmations aimed at improving self-image, inserted with analog electronic circuit below the music to make them go unnoticed (see Discussion below). Some tapes also included a few statements of this kind that were perfectly audible. Also, on the case label, besides the usual comments about the advanced techniques and effectiveness of the tapes, there were some examples of the statements included in the recording. such as, I am a unique and distinctive being; It is in my power to create my reality, and so on.

There were three kinds of tapes:

1. Subliminal, containing music and subliminal selfaffirmations.

2. Sub-suptaliminal, containing music and both subliminal (the same as in 1) and supraliminal self-affirmations.

3. Placebo, containing only the music and the case label (which, as mentioned, stated that it contained effective subliminal self-affirmations).

The Tennessee Self-Concept Scale (ISCS; Fitts, 1965). In order to measure self-esteem, we used an experimental adaptation of 'TSCS developed in Spain by Garanto (1984). The TSCS is a five-point Likert-type scale where respondents are requested to describe the way thcy perceive themselves, It is made up of 100 items, distributed in five large subscales (physical, moral-ethical, personal, family, and social selfconcept), which provide a global self-esteem score. Garanto foutd that his Spanish version of the scalc has external and construct validity, and reliability indexes very similar to those reported in the original studies. The test-retest reliability of the Spanish version is .85.

\section{Procedure}

The study was carried out in two group sessions of one hour each; plus the time spent listening to the tape, which cach participant did individually in-between the two sessions.

In the first session, which took place during the lecture hours of an unrelated subject, the students were informed about the existence of audiotapes and CDs with subliminal messages designed to improve a variety of human resources, among them, self-esteem. They were also informed that our aim was to check their effectivencss, attempting 10 be impartial, without prejudging the results. Therefore, we asked for the collaboration of volunteers who were willing to try to itcrease their self-esteem by this process. The volunteers were then told they should try to listen to the tape daily -or at least 30 times-before the following session, 48 days later. They were informed that they could listen to it while performing other normal activities, but that it was preferable to do so using headphones, while comfortable and relaxed.

They were then given the questionnaire to fill in and, at the same time, the tapes (subliminal, sub-supraliminal, and placebo) were handed out at random, coding the experimental condition (i.e., type of tape) assigned to each participant. By means of the instructions given in the pretest session, all of the participants were led to believe that all of the tapes, as stated in the case labels, contained subliminal messages, in addition to some containing similar audible messages. 
In the second session, 48 days later, participants were given another copy of the questionnaire, with a series of additional questions at the end, aimed at obtaining information about their confidence in the procedure and the approximate number of times they had listened to the tape. Lastly, they were informed about the different experimental conditions, without identilying which one each participant had undergone.

\section{Design}

The participants were randomly assigned to one of the following four groups.

Subliminal group: Participants assigned to this condition received the subliminal tape. Of the 31 persons in this condition that filled in the TSCS in the pretest session, 20 did so again (correctly) in the posttest session.

Sub-supraliminal group: Participants assigned to this condition received the sub-supraliminal tape. Of the 31 that filled in the questionnaire correctly in the pretest. 22 did so again in the posttest.

Placebo group: Participants assigned to this condition received the tape with only music. Of the 31 participants assigned to this condition, 22 answered the questionnaite correctly in the posttest.

Waiting group: The participants assigned to this condition were not given tapes until the posttest session. In the first session, they simply filled in the questionnaire, and were informed that they would not receive the tapes until the following session. Of the 32 participants in this condition, only 19 correctly filled in the questionnaire and collected the tape with the subliminal messages in the following session.

Thus, we used a $4 \times 2$ mixed factorial design, the lirst factor between-subjects and the second withill-subjects. In order for the design to be suitable for testing the interaction between the subliminal and supraliminal messages, a group with just supraliminal messages should have been included. Unfortunately, NAC's lack of tapes with only supraliminal messages precluded the introduction of such a condition and the completion of the design in this sense. However, if no significant differences between the sub-supraliminal group and the subliminal or the placebo groups are revealed, we can rule out such interactive influence. Nevertheless, the presence of significant differences must not necessarily be attributed to interaction, because it could also -ind quite probably-be duc to the exclusive incidence of the supraliminal messages.

\section{Results}

The data of 42 participants had to be discarded from the analysis either because it was incomplete (three cases) or due to their failure to attend the postlest ( 39 cases). Of the remaining 83 participants, 20 belonged to the subliminal group, 22 to the sub-supraliminil, 22 to the placebo group, and 19 to the waiting group. Table I shows the means and standard deviations of the pre- and posttest self-esteem scores of the four experimental groups.

Given the mixed fuctorial design, we first verified the assumptions of equality of variances and compound symmetry. Levene's contrast indicated a critical level of .133 for the pretest and .519 for the posttest, which allowed us to maintain the hypothesis of equivalence of variances in both cases. On the orher hand, the Box test produced a critical level of .459 , which allowed us to assume equality of the covariance matrices.

We performed an analysis of variance (Groups $\times$ PrePost Measurement), which allowed us to make the following three main observations. Firstly, no differences between groups was observed for the two mentioned measurements considered jointly, $F(3,79)=0.40 . p=.752$. Sccondly, we found a higher posttest $(M=3.71)$ than pretest $(M=3.55)$ score in the self-esteem questionnaire, $F(1,79)=3.76, p=$ .0001 . 'l'hirdly, a significant interaction elfect was observed, $F(3,79)=2.73, p=.049$.

This implies that, overall, there was no marked difference between the groups, that the self-esteem score improved from the first to the second measurement, and that this improvement was not the same in all groups. Specifically, the t-test subsequently applied showed that there were statistically signiticant differences in the subliminal group, with a mean incrase of $0.14 . t(19)=3.40, p=.003$; in the

Table 1

Means and Standard Deviations of PrefPosttest Scores in the Tennessee Self-Concept Scale for the Four Groups

\begin{tabular}{lccccc}
\hline \multirow{2}{*}{ Groups } & \multicolumn{2}{c}{ Pretest } & & \multicolumn{2}{c}{ Postest } \\
\cline { 2 - 6 } & $M$ & $S D$ & $M$ & $S D$ & $n$ \\
\hline Subliminal & 3.60 & 0.40 & 3.74 & 0.41 & 20 \\
Sub-Supraliminal & 3.57 & 0.49 & 3.83 & 0.53 & 22 \\
Placebo & 3.46 & 0.43 & 3.65 & 0.45 & 22 \\
Waiting & 3.57 & 0.57 & 3.62 & 0.51 & 19 \\
Total & 3.55 & 0.47 & 3.71 & 0.47 & 83 \\
\hline
\end{tabular}


sub-supraliminal group, with a mean increase of $0.26, t(21)$ $=4.07, p=.001 ;$ and in the placebo group, with a mean increase of $0.19, f(21)=4.00, p=.001$; whereas in the waiting group, whose mean increase was $0.05, t(18)=1.04$. $p=.311$, there was no such improvement.

In this sense, subsequent unifactorial (treatment of each group) ANOVA of the pre/posttest gains revealed statistically significant group differences: $F(3,79)=4.03, p=.014$. Multiple post hoc comparisons, estimated by means of 'Tukcy"s HSD test, revealed significant differences between the waiting group and the remaining groups (that is, groups which heard one of the tapes). The three groups that heard one of the tapes during treatment showed statistically significant score increase, as compared with the waiting group, with a mean difference of $0.10(S D=0.04), p=$ .043 , in the case of the subliminal group; and of 0.20 (SD $=0.06), p=.011$, in the sub-supraliminal group; and of 0.14 $(S D=0.05), p=.018$, in the placebo group. A statistically significant score increase in the sub-supraliminal group was also observed, as compared with the subliminal group, with a mean difference of $0.12(S D=0.05), p=.027$. There werc no statistically significant differences between the placebo group and the subliminal group (the mean difference was of $0.05, S D=0.05, p=.621$ ), nor between the placebo group and the sub-supraliminal group: the mean difference was $0.06(S D=0.06), p=.568$.

\section{Discussion}

Our data indicate that the improvement in the three groups receiving tapes was not due to the passing of time, measurement repetition, or the like. However, the fact that there are similar improvements in the groups receiving tapes with and without subliminal messages indicates that a placebo effect occurred, rather than an effect actually resulting from the concealed content as such. Although improbable, one could also speculate that the effects were due to the music (since the only group that did not improve is the one that did not receive the tape), but in no way were they due to the subliminal messages. Thus, despite the acknowledged insufficiency of the design, all of the effects observed could be explained in terms of placebo.

The results of this study do not support the capacity of auditory subliminal messages - as they were used here- to increase self-esteem. This is in accordance with some previously mentioned studies (Greenwald et al., 1991; Lenz, 1989; Merikle \& Skanes, 1992; Russell et al., 1991), either using the same variable (self-esteem) or others, such as the improvement of memory, academic performance, and motor skills, or weight loss in obese people. Naturally, this may be due to the fact that messages of this nature are not processed or, if they are, do not have the kind of effect sought by these studies. As already mentioned, there is empirical evidence and theorctical reasons to suspect that unnoticed information can only be processed when it involves simple and familiar stimulj that have a specific permanent representation in the mental knowledge system; i.e., in the case of verbal information, probably words (especially when presented visually), but not sentences (especially when presented aurally). On the other hand, most of the effects observed in experimental research on unconscious perception are related to parameters that are more "sensitjve" and susceptible to modification than those used in our tapes, which are about everyday lile aspects.

Ont the other hand, as Greenwald et al. (1991) also observed, the tapes with subliminal messages generated placebo effects, which are frequent in situations vulnerable to the influence of expectations (Kirsch, 1999; Kirsch \& Sapirstein, 1999; Priolcau, Murdock, \& Brody, 1983). Placebo treatment produced a moderate increase in selfconcept scores from pretest to posttest, but retiable and no smaller than the onc observed in the subliminal condition. Allhough in other studies no such influences were found (e.g., Lenz, 1989; Merikle \& Skanes, 1992), the aim of subliminal tapes in these cases was to reduce weight or to improve academic achievement and motor skills performance, outcomes surely less vulnerable to placebo effect than self-concept.

The above-mentioned data and our own results are not in accordance with those obtained in a series of studies in which genuine effects of subliminal messages were observed (e.g., Costello \& Budzynski, 1991; Doche-Budzynski. \& Budzynski, 1989; Kolzé \& Möller, 1990; Monahan, 1991; Reid, 1990; see Swingle, 1992, for a general discussion and review). The discrepancy may be due to the fact that, in these cases, the verbal messages were occasionaliy perceived consciously (we hardly need remind the reader of how difficult it is to guarantee the total absence of consciousness) or to some other reason (as mentioned, most of the studies are considered preliminary by their own authors). Besides, Kotzé and Möller did not use typical tapes with phrases designed to improve some personality aspect, but tapes including isolated words with emotional content, recording their effect on GSR increase, as reported earlier by Borgeat, Boissonneault, Chalout, and Elie (1989). However, from the data currently available, it would seem premature to discard all possible effectiveness of this type of subliminal auditory messages. The contrary results to the efficacy of subliminal messages obtained so far, at least those obtained in our study, given its limitations, may well have various causes.

In the first place, our participants were not seeking help to increase their self-esteem, nor did they turn to these procedures on their own initiative; quite probably, most of them had no particular problems in this respect. This differentiates them markedly from people who decide to spend money on tapes with subliminal messages. The latter presumably have self-esteem problems, are making an effort to increase it, and are willing to use this type of material. In the second place, no doubt partially because of this, most 
of the participants (as they admitted in the addendum to the posttest questionnaire) did not listen to the tape a sulficjent number of times -many not anywhere near the 30 times that is usually the recommended minimum. In this sense, Reid (1990) observed the relevance of exposure-time dosage: $\mathrm{Hc}$ found no effect of the subliminal messages until participants were exposed to the tapes for more than 15 hours. Taylor (1988) reported a similar tendency. Therefore, this circumstance should be taken into account in future rescarch.

Another main factor should also be considered: Not all tapes with subliminal messages are generated with the same technique. These variations can lead to great differences in the signal/noise ( $\mathrm{S} / \mathrm{N}$ ) ratio necessary for mossages (the signal) to be masked by the noise and, thus, escape notice. These differences can be relevant in terms of whether or not the hidden messages are processed and generate effects. Urban (1992) described four techniques, which result in very different products (i.e., tapes).

Historically, the first method of generating imperceptible auditory messages has been the simple reduction of amplitude or intensity of the sound until it becomes indistinguishable: the threshold technique. This rudimentary technique practically requires the signal to be destroyed if it is to be guaranteed that the messages will not be consciously heard. A more advanced procedure consists of masking the signal with other more intense sounds or music, until the former becomes imperceptible. Within this approach, the most rudimentary option is to record the noise at a certain mean level of intensity and the signal. at a markcdly lower mean volume level, so that the latter is undetectable once mixed with the noise. The main problem with this technique is that, with signals and noise that vary greatly in terms of both amplitude and frequency (speech and music are both broadband), in order for the messagc to be undetectable, the average difference in decibels must be very large: about $45 \mathrm{~dB}$ or more.

A lechnically more advanced variation of the above procedure consists of using equipment with an analog electronic circuit that continually adjusts the $S / N$ ratio to a pre-selected level. This technique, introduced in the late 1960 s by Becker (Becker, 1966; Becker, Charbonnet, Marino, Steck, \& Warren, 1980) and which is popularly known as the black box, undoubtedly represents a great advance with respect to previous procedures. However, in order to guarantee that the messages are not consciously heard, they must fluctuate within a band of $25-35 \mathrm{~dB}$ below the noise, which may also prevent their sensorial registration. Modern techniques of digital signal processing (DSP) allow enormous refinement of the conventional subliminal mixers by a much quicker and more detailed analysis of signals, their compression, acceleration, and filtering in multitracking systems, hamonization of the voice and music frequencies, and so on. This allows masking verbal messages with presentations only $10-15 \mathrm{~dB}$ below the noise. Such innovations, which are not yet usually employed in subliminal tape production, may bring about important improvements in masking signals that still remain processable by the auditory system.

It is therefore nol surprising that tapes recorded with techniques other than DSP (such as analog electronic circuit to adjust the $\mathrm{S} / \mathrm{N}$ ratio to pre-selected level, as used in ours and in practically every tape mentioned here: e.g.. Greenwald et al.. 1991; Lenz, 1989; Russell et al.. 1991), should present an $S / N$ relationship that makes it impossible to process the signal. This could make a definite difference in the possibility of processing the messages, and in the efficacy of subliminal audiotapes and CDs.

In sum, our results do not show genuine inlluence of subliminal verbal messages on audiotapes for increasing selfestecm, but only placebo effect. Nevertheless, due to the various limitations of ours and simjlar studies, and bearing in mind the opportunities provided by modem digital recording techniques, we believe thit, under appropriate conditions, the possibility of this treatment improving human resources to some extent should not be definitely ruled out. A variety of citcumstances may influence this kind of effects: the nature and content of messages (sentences or isolated words), recording techniques and corresponding $S / N$ ratjo, exposuretime dosage type of resource or clinical problem involved, circumstances in which people opt for this treatment, etc. Future research should take note of the new technical conditions and continue to explote different pathways. We emphasize that, in recent years, the human mind has proven to be capable of processing far more than the information of which we are conscious. The limits of that capacity, as well as its possible effects, remain to be established. The experimental evidence available up to now about the itifluence of subliminal audiotapes suffers from a lack of consistency and diversity, which should be corrected in the future.

\section{References}

Becker, H.C. (1966). Apparatus for producing visual and auditory stimulation. United States Patent $N^{*} 3.278,676$.

Becker, II.C., Charhonnel, K.D., Marino. D.R., Steck, C.G., \& Warren. E.S. (1980). Subliminal communication: New processors for therapy, indesstry and edncation. Demonstration exhibited at the 33rd Annual Conference on Engineering in Medicine and Biology, Washington, DC.

Bentin, S., Kutas, M., \& Hillyard, S.A. (1995). Semantic processing and memory for attended and unattended words in dichotic listening: Behavioral and electrophysiological evidence. Joumal of Experimental Psychology: Haman Pereption and Performance. 21, 54-67.

Borgeat. F. Boissonneault, J., Cbalout, L., \& Elic, R. (1989), Psychophysiological responses to subliminal auditory suggestions for activation. Perceptual and Motor Skills, 56. 759-765.

Bonstcin, R., \& Pitman, T. (Eds.). (1992). Perception without anareness. New York: Gutilford Piess. 
Chimera, D.M. (1987). An exploration of the effect of auditory subliminal stimuli on schizophrenic pathology. Dissertation Abstracts Intemational, $48,1509 \mathrm{~B}$.

Costelo, R.B., \& Bud\%ynski, T. (1991, June). Subliminal atudiotapes as a p.sychotherapeluic modality. Paper presented at the Annual Meeting of the International Socicty for Preconscious Learning, Las Vcgas. NV.

Dehaene, S., Naccache. L., Le Clec'H, G. Koechlin, E., Mueller, M., Dehacne-Lalnbert7, G., van de Moortele, P-F.. \& I_e Bihan, D. ([998). Imatging unconscious scmantic priming. Nature, $395,597-600$.

Doche-Budzynski, L., \& Budzynski, T. (1989). Subliminal selfesteem enhancement in adult Type A males. Education, 10 , 50-55.

Draine, S.. \& Greenwald, A.G. (1998). Replicable unconscious semantic priming. Joumal of Experimental Psychology: General, 127, 286-303.

Durkin. K. (1998). Implicit content and implicit processes in mass media use. In K. Kirsner. C. Speelman. M. Milybery, A. O'Brien-Malone, M. Anderson, \& C. MacLeod, (Eds.). Implicit and explicit mental processes. Mahwah, NJ: Erlbaum.

Fitts, W.H. (1965). Tennessee Self-Concept Scale: Mantal. Nashvillc, TN: Counselor Recording and Test.

Froufe, M. (1997). El incomsciente cognitive: la cara oculta de la mente. Madrid: Biblioteci Nueva.

Garanto, J. (1984), Las actitudes hacia si mismo y su medición. Barcelona: EU Temas de Psiculogía 7.

Greenwald, A.G., Spangenberg. E.R., Pratkanis, A.R., \& Skenari, J. (1991). Double blind tests of sublinuinal self-help audiotapes. Psychological Science, 2, 119-122.

Kirsch, 1. (Ed.). (1999), How expectancies shape experience. Washingtom, DC: American I'sychological Association.

Kirsch. I., \& Sapirstein, (j. (1999). Listening to Prozac but hearing placebo: A meta-analysis of antidepressant medication. In 1 . Kirsch. (Ed.). How expectancies shape experience (pp. 303320). Wastrington, DC: American Psychological Association.

Kotzé. H.F., \& Möller, A.T. (1990). Effect of auditory subliminal stimulation on GSR. Psychological Reports. 67, 931-934.

Lenz, S. (1989). The effects of subliminal auditory stimuli on academic leaning and motor skils perfomance among police recruits. Unpublished doctoral dissertation, Californta School of Professional Psychology.

Merikle, P.M., Joordens, S., \& Stolz, J.A. (I995). Measuring the relative magnitude of unconscious influences. Consciousness and Cogrition, 4, 422-439.
Merikle, P.M., \& Skanes, H.E. (1992). Subiminal self-help audiotanes: A scarch for placebo effects. Journal of Applied Psychology, 77, 772-776.

Monahan, R. (1991). Subliminal audio as an adjunct to traditional welve-step oriented treament for chemical dependency-pilot project. Philadelphia, PA: Livegrin Foundation.

Neuberg, S.L. (1988). Behavioral implications of information presented outside of conscious awareness: The effect of subliminal presentation of trait information on behavior in the prisoner's dilenma game. Srcial Cognition. 6. 207-230.

Ohman. A., \& Soares, J. (1998). Emotional conditioning to masked stimuli: Expectancies for aversive outcomes following nonrecognized fear-relevant stimuli. Journal of Experimental Psychology: General, 127, 69-82.

Pittman, T.S., \& Bornstein, R.F. (1989, April). Nonconscious biasing effecs in hiring decisions. Communication presented to the LX Annual Conference of the Eastern Psyctrological Association, Boston, MA.

Prioleau, L., Murdock, M.. \& Brody. N. (1983). An analysis of psychotherapy versus placebo studies. Behavioral and Brain Sciences, 6, 275-310.

Reid, J. (1990). Fre? of depression: Subliminal fape study. Unpublished master's thesis, Colorado State University, $C O$.

Russell, T., Rowe, W. \& Smouse. A. (1991). Sublininal self-help tupes and academic achicvement: An evaluation. Joumal of Connseling and Development, 69, 359-362.

Silverman, L.H. (1983). The subliminal psychodynamic activation method: Overview and comprehensive histing of studies. In J. Masting (Ed.), Enpirical studies of prychoanalytic theories. (Vol, L, pp. 69-100). Iillsdale, NJ: Erlbaum.

Swingle, P.G. (1992). Subliminal treatmen procedures: A climicians" ginde. Sarasota, FL: Professional Resource Press.

Taylor, E. (1988). Subliminal learning: An eclectic approach. Salt Lake City, UT: Just Another Reality.

Urban, M.J. (1992). Auditory subliminal stimulation: $\Lambda$ reexamination. Perceptual and Motor Skills, 74, 515-541.

Vila, J.. \& Tudela, P. (1982). Procesamiento semántico no consciente durante una tarea de atención dicótica. Psicológica, 3, 5-23.

Weiskrantz, L. (1997). Consciousness lost and found: A neuropychological exploration. Oxford. UK: Oxford University Press.

Received September 28, 1999

Revision received March 29, 2000

Accepted May 19, 2000 